\title{
FANCE Gene Amplification
}

National Cancer Institute

\section{Source}

National Cancer Institute. FANCE Gene Amplification. NCI Thesaurus. Code $C 131455$.

A molecular genetic abnormality indicating the presence of multiple copies of the FANCE gene. 